\title{
CZYNNIKI NARODOWY I PAŃSTWOWY W ROZWOJU MORALNYM CZŁOWIEKA A PROBLEM PATRIOTYZMU. REFLEKSJA W OPARCIU O MYŚL PEDAGOGICZNĄ JACKA WORONIECKIEGO OP (1878-1949) - KONTEKSTY WSPÓŁCZESNE
}

National and State Factors in Man's Moral Development and the Problem of Patriotism. Reflections based on the Pedagogical Thought of Friar Jacek Woroniecki (1878-1949): Contemporary contexts Summary: The aim of the article is to interpret Jacek Woroniecki's concept of "nation" and "state" in the contemporary contexts of globalisation and cultural integration with a view to re-defining patriotism. The article consists of three parts. Part 1 poses the question about the importance of a nation and a state for man's life. Part 2 discusses the issue of national tradition seen as a controversial factor of modern patriotism. Part 3 presents Woroniecki's ontology of the nation and the state. Raising these important topics provides the author with an opportunity to popularise the thoughts of the Polish educator.

Following the analysis, the article demonstrates that the concept of contemporary patriotism should not only take into account the cultural factor, but also that it should not juxtapose it with the legislative one. It argues that both types of communities, i.e. the nation and the state, affect the development of man's personal identity and social activities. To be more specific, the nation and the state use different, albeit complementary, means in educating

1 Dr hab. Maria Małgorzata Boużyk - adiunkt w Katedrze Filozofii Wychowania Wydziału Nauk Pedagogicznych Uniwersytetu Kardynała Stefana Wyszyńskiego w Warszawie. Adres WNP UKSW, ul. Wóycickiego 1/3, bud. 15, 01-938 Warszawa; e-mail: m.bouzyk@uksw.edu.pl. 
the individual: while the nation exerts influence on the character of the members of the community through customs, the state cares about laws. By clarifying the ontic determinants of both social formations, the article reveals the fundamental principle of their existence, i.e. moral education of the individual. This principle is of universal significance and it can be helpful in re-defining patriotism in a way suitable to the needs of contemporary culture.

Keywords: nation, state, patriotism, globalism, integration processes, moral development, tradition

W artykule podejmuje się problem aktualności myśli pedagogicznej Jacka Woronieckiego ${ }^{2}$ na temat roli czynnika narodowego i państwowego $\mathrm{w}$ rozwoju moralnym człowieka. Ten kierunek analiz podpowiadają współczesne dyskusje toczące się w polskiej przestrzeni publicznej wokół problemu istnienia państwa narodowego w dobie trwających procesów integracyjnych w Europie oraz rzeczywistości kultury i gospodarki globalnej. Ich wyrazem jest m.in. propozycja redefinicji pojęcia patriotyzmu w kluczu Habermasowskiego ujęcia, w której dokonuje się przeniesienia akcentu z czynnika kulturowego na rzecz prawnego w określaniu postaw patriotycznych ${ }^{3}$.

Należy dokładać wszelkich starań, by w trwających debatach argumenty polityczno-ekonomiczne nie przesłaniały moralnych, ponieważ tylko dzięki krytycznej ocenie wartości, wokół których integruje się społeczeństwo, uzyskuje się wgląd w kwestie kluczowe dla wychowania młodych pokoleń. Zrozumiałe jest, że w upominaniu się o ujawnienie aksjologicznego kodu obserwowanych przemian znaczące miejsce przypada refleksji pedagogicznej, w tym próbom

2 Jacek Woroniecki (1878-1949): dominikanin, teolog, filozof, pedagog, rektor UL (przedwojenny KUL), profesor Collegium Angelicum - znacząca postać życia religijnego, kulturalnego okresu międzywojnia.

3 Powojenne dyskusje intelektualistów niemieckich koncentrujące się wokół problemu odpowiedzialności Niemiec za II wojnę światową inspirowały poszukiwania nowej zasady tożsamości narodowej Niemców. Zaczęto upatrywać jej w wartościach demokratycznych, a nie, jak dotychczas, w pojęciu narodu. W latach sześćdziesiątych została wstępnie wypracowana (Dolf Sternberger) koncepcja patriotyzmu konstytucyjnego zorientowanego na państwo i jego instytucje. Ostatecznego kształtu zaczęła nabierać w latach osiemdziesiątych dzięki badaniom Jürgena Habermasa, a po przejściu swego rodzaju testu na początku lat dziewięćdziesiątych w związku ze zjednoczeniem NRD i RFN stała się projektem o znaczeniu uniwersalnym. Rozwijając swoją koncepcję, Habermas zaczyna pokazywać ją jako interesującą dla organizacji nowoczesnych społeczeństw, których stabilność wobec różnic kulturowych i religijnych ich członków powinna opierać się nie na tradycji, ale na prawie (konstytucyjne państwo prawa). Zob. Jürgen Habermas, Obywatelstwo a tożsamość narodowa. Rozważania nad przyszłościa Europy, przeł. B. Markiewicz (Warszawa: Instytut Filozofii i Socjologii PAN 1993), 26. W związku ze zmianami ustrojowymi w Polsce i jej wstąpieniem do UE dyskusje nad formą patriotyzmu nabrały zrozumiałego znaczenia także dla polskiego społeczeństwa. Zob. np. pracę Marcina Króla, Patriotyzm przyszłości (Warszawa: Wydawnictwo „Szklane Domy" 2004). 
zastosowania $\mathrm{w}$ badaniach instrumentarium pojęciowego już wypracowanego przez pedagogów. Przywołanie wypowiedzi Woronieckiego o narodzie i państwie wydaje się zasadne, tym bardziej że autor łączył wspomniane kwestie z zagadnieniem patriotyzmu ${ }^{4}$.

Zaznaczmy, że w trwającym od wielu lat przywracaniu tekstów Woronieckiego dla współczesnej pedagogiki nie pominięto także jego koncepcji narodu i państwa $z$ jej wychowawczymi implikacjami ${ }^{5}$. Kontynuując to dzieło, spróbujemy zastosować tę koncepcję do przedstawienia kilku uwag odnośnie do poszukiwań formuły patriotyzmu adekwatnej do współczesnych uwarunkowań społeczno-kulturowych. Naszą analizę podzieliliśmy na trzy części. W pierwszej zastanowimy się nad zasadnością pytania o wymiar narodowy i państwowy ludzkiej egzystencji w kontekstach aktualnych przemian polityczno-gospodarczych, w drugiej i trzeciej - podejmiemy próbę odpowiedzi na to pytanie, podążając za rozwiązaniami, które można znaleźć w tekstach Woronieckiego. Dlatego zastanowimy się nad kwestią obyczaju jako czynnika integrującego społeczność i ontologicznymi uwarunkowaniami koncepcji narodu i państwa.

\section{Pytanie o konieczność życia w narodzie i państwie}

Od czasów nowożytnych pojęcia narodu i państwa nierozerwalnie kojarzą się z myśleniem o ojczyźnie, jakkolwiek jest ona fenomenem złożonym, przede wszystkim tworzą ją ludzie. Pojawia się więc pytanie o znaczenie tak rozumianej ojczyzny (wspólnoty) w rozwoju osobowym. W analizie tekstów Woronieckiego wyraźnie wybrzmiewa znacząca wychowawczo rola środowiska społecznego. Przytoczmy jeden fragment z jego wypowiedzi, dotyczący tej kwestii, ale odnoszący się już konkretnie do interesujących nas wspólnot - narodu i państwa:

Źródłem konieczności życia w narodzie i państwie jest potencjalność naszej natury, a jeszcze dalej w ukształtowaniu natury ludzkiej, w istotnym połączeniu duszy z ciałem. Człowiek z natury nie otrzymuje prawie nic gotowego do użycia, wszystko

4 Zob. Jacek Woroniecki, Katolicka etyka wychowawcza (Lublin: Redakcja Wydawnictw KUL, 1986), t. 2-2, 122.

5 O marginalizowaniu pedagogiki Woronieckiego w dobie ideologii marksistowskiej świadczy choćby publikowanie w tym czasie jego prac tylko w kręgach katolickich. Kluczowe dzieło pedagoga, Katolicka etyka wychowawcza, doczekało się dopiero wydania w 1986 roku, a więc długo po śmierci autora. W kolejnych latach były publikowane także zbiory jego artykułów z okresu międzywojnia, w tym w roku 2004 Quaestio disputata de natione et statu civili - O narodzie i państwie (tekst przełożył z łaciny i opatrzył komentarzem R. Maliszewski).

Pedagogika Woronieckiego jest dziś przedmiotem rozważań wielu badaczy (także autorki). Najnowsza publikacja została przygotowana przez Ryszarda Polaka (2017). Wśród publikacji dotyczących interesującej nas kwestii można wymienić m.in. teksty następujących autorów: Marii M. Boużyk (2017), Dobrochny Bach-Goleckiej (2008), Jacka Grzybowskiego (2010; 2012; 2016); Katarzyny Kalinowskiej (2006), Ulricha Schradego (2000). 
musi wypracować, oczywiście w ramach swojej natury. Praca ta nie może odbyć się bez pomocy innych ludzi [wyróżnienia moje - M.B.] .

O jakiej konieczności pisze pedagog w zacytowanym tekście? Czy chodzi np. o jakąś konieczność warunkowaną tylko historycznie czy o coś więcej? Biorąc pod uwagę niektóre współczesne interpretacje socjologiczne, politologiczne i ekonomiczne społecznego rozwoju, można przypuszczać, że zmierza on do coraz wyraźniejszej unifikacji poprzez tworzenie struktur ponadnarodowych i ponadpaństwowych ${ }^{7}$. W związku z tym wypowiedzi Woronieckiego na temat roli narodu i państwa w formacji moralnej człowieka wydają się uwarunkowane historycznie: zmieniły się czasy, a więc i zmieniły się czynniki, które odpowiadają za rozwój społeczny jednostek ${ }^{8}$. Kiedyś tym czynnikiem było państwo narodowe i ideologia nacjonalizmu, dziś, tj. w czasach globalizacji i trwających procesów integracyjnych, relacje społeczne wymagają innego spoiwa. Ciekawe, że we wspomnianych współczesnych diagnozach kluczowym kryterium rozwoju społecznego jest postęp cywilizacyjny i gospodarczy, a nie moralny. W świetle tego kryterium państwo narodowe jest postrzegane jako twór anachroniczny, który odegrał już swoją historyczną rolę: dzięki niemu w XX wieku wyłonił się system światowego kapitalizmu. Zwolennicy globalizacji uważają je nawet za przeszkodę w nieskrępowanym rozwoju gospodarczym, który traktują jako najwyższe dobro i korelat wolności. Ich zdaniem korporacje transnarodowe, a nie narody i państwa narodowe, mają ostatecznie wyznaczać mapę polityczną świata ${ }^{9}$. Globalizacja jest więc traktowana jako finalny etap modernizacji, tj. zwycięstwo ideologii zachodniego liberalizmu (wobec upadku marksizmu), a procesy integracyjne uznawane za nieuniknioną konsekwencję tej modernizacji.

Wracając do myśli Woronieckiego i pytania o konieczność życia w narodzie i państwie, nie można oczywiście zaprzeczyć, że pedagog w filozofii szukał wskazówek dla rozwiązywania problemów wychowania nie tyle w wymiarze ogólnym, co w konkretnej sytuacji społeczno-kulturowej okresu międzywojnia. Były to czasy, w których kwestie narodowe stały się ważnym punktem odniesienia dla formacji młodych pokoleń, w szczególności Polaków, ze względu na odzyskanie

${ }^{6}$ Jacek Woroniecki, Quaestio disputata de natione et statu civili - O narodzie i państwie, przeł. R. Maliszewski (Lublin: Fundacja Servire Veritati Instytut Edukacji Narodowej 2004), 64.

7 Zob. np. Kazimierz Krzysztofek, Marek S. Szczepański, Zrozumieć rozwój. Od społeczeństw tradycyjnych do informacyjnych (Katowice: Wydawnictwo Uniwersytetu Śląskiego 2005).

8 W duchu przemian historycznych kwestie narodowe będą postrzegane przez np.: Zygmunta Baumana, Globalizacja i co $z$ tego dla ludzi wynika, przeł. Ewa Klekot (Warszawa: Państwowy Instytut Wydawniczy 2000), 56-91; Alvina Tofflera, Trzecia fala, przeł. Ewa Woydyłło, Michał Kłobukowski (Warszawa: Państwowy Instytut Wydawniczy 1997), 470-495 i 566-583; Francisa Fukuyamę, Koniec historii, przeł. Tomasz Bieroń, Marek Wichrowski (Poznań: Wydawnictwo Zysk i S-ka 1997), 295-305.

9 Zdaniem Krzysztofka i Szczepańskiego w tej kwestii znacząca jest praca na temat globalizacji brytyjskiego socjologa Martina Albrowa (Krzysztofek, Szczepański, Zrozumieć rozwój, 252). 
przez Polskę państwowości. Zarazem był to okres narastania ruchów skrajnie nacjonalistycznych. Obie te kwestie rysują historyczny kontekst podjętych przez Woronieckiego badań, bez wątpienia będąc inspiracją zarówno do namysłu nad patriotyzmem, jak i ideologią skrajnego nacjonalizmu (Woroniecki nazywał go też liberalnym). Przywołany na wstępie naszych rozważań cytat pochodzi z jego rozprawy $O$ narodzie i państwie wydanej w połowie lat dwudziestych ${ }^{10}$, a zatem przed II wojną światową, zanim Europa doświadczyła tragicznych skutków skrajnie nacjonalistycznych ideologii.

Woroniecki dostrzegał niszczący wpływ tych ideologii na jednostkę i więzi społeczne, w związku z tym wskazywał na ich filozoficzne uwarunkowania, dostrzegając je w oświeceniowej zmianie koncepcji społeczeństwa jako idei (umowy) politycznej, a przede wszystkim w antropologii indywidualizmu. Biorąc pod uwagę przywoływane analizy socjologiczne, traktujące globalizm jako ostatnie ogniwo łańcucha ewolucji społecznej, z nacjonalizmem jako ogniwem wcześniejszym, można powiedzieć, że oba czynniki determinujące dziś myśl społeczną pozostały niezmienione. Nadal mamy do czynienia $\mathrm{z}$ antropologią indywidualizmu i tą samą koncepcją społeczeństwa. Tak więc koncepcje filozoficzne, na które wskazywał Woroniecki w latach dwudziestych, nadal są powtarzane, a w związku z tym pytanie o konieczność życia w narodzie i państwie zachowuje swoją aktualność także w nowym kontekście historycznym.

Idąc śladami Woronieckiego, należy przenieść poszukiwanie odpowiedzi na zadane pytanie z płaszczyzny socjologicznej na poziom ontologii (i jej konsekwencji w dziedzinie etyki). Zasadność tego kierunku rozważań potwierdza klasyfikacja koncepcji narodu zaproponowana przez Jacka Grzybowskiego ${ }^{11}$. Dla nas szczególnie istotna jest jej dychotomiczna podstawa. Mianowicie filozof dzieli koncepcje narodu ze względu na ich ontologiczne uwarunkowania, które czerpią bądź z tradycji realistycznej, bądź idealistycznej metafizyki. Woroniecki, co wyjaśnimy w dalszej części naszych rozważań, odwołuje się do koncepcji filozofii realistycznej (tomizmu) i w oparciu o nią wypowiada się o roli narodu i państwa w rozwoju moralnym człowieka.

10 Tekst pierwotnie został opublikowany na łamach czasopisma „Divus Thomas” 29 (1926), nr 1. W podobnym duchu wybrzmiewa inny tekst autora Nacjonalizm a katolicyzm (1924). Oba teksty zostały wydane w 2004 roku w ramach wspomnianej już publikacji - zob. Woroniecki, Quaestio.

${ }_{11}$ Zob. Jacek Grzybowski, Byt, tożsamość, naród. Próba wyjaśnienia formuly „tożsamość narodowa" w perspektywie metafizyki (Kęty: Wydawnictwo Marek Derewiecki 2012), 546-629. 


\section{Wychowawcza wartość obyczaju}

Tradycję, inaczej - obyczaje, tworzą formy zachowania, tzn. różne sposoby reagowania na to, co spotyka człowieka w codziennym życiu. Tworzenie się obyczajów to długi proces akumulacji doświadczeń przeżywanych przez społeczność narodową w świetle kluczowych dla niej wartości. Obyczaje mogą więc podlegać zmianie. Woroniecki zauważa: „Zbytnie przywiązanie do obyczajów, do tego, co było, jest cechą zacofania i może być bardzo szkodliwe dla życia moralnego, które z rozwojem warunków społecznych ulega zmianom [...]"12.

Należy zaznaczyć, że według myśliciela obyczaj, chociaż nie jest czymś przyrodzonym, ale ustanawianym przez społeczność, ma charakter prawa moralnego i dlatego wiąże człowieka w sumieniu ${ }^{13}$. Jednocześnie pedagog wyjaśnia, że naród, który w procesie oddziaływania obyczajowego na jednostkę przekracza granice dozwolone przez prawo moralne, znieprawia charaktery i traci rzeczywistą jedność i samodzielnośćc ${ }^{14}$. Dodajmy za innym kontynuatorem tradycji filozoficznej bliskiej Woronieckiemu, Mieczysławem A. Krąpcem, że o jedności narodu decyduje to, czy i na ile cel narodowej wspólnoty zostanie uzgodniony z ostatecznym celem człowieka ${ }^{15}$. Jako egzemplifikację prowadzonych w tym duchu ocen można przytoczyć polską myśli niepodległościową po klęskach powstań narodowych. $\mathrm{Z}$ analizy Jacka Salija, którego prace również są bliskie wykładni ideowej właściwej Woronieckiemu, wynika, że wyzwolenie narodowe zaczęto splatać z wyzwoleniem społecznym i uregulowaniem stosunków z narodami współzamieszkującymi dawną Rzeczpospolitą: Białorusinami, Litwinami, Ukraińcami i Żydami ${ }^{16}$.

Oczywisty w związku z tym jawi się postulat Woronieckiego, aby badać zasoby kulturowe narodu: w narodowej kulturze wyraża się specyfika narodu, a więc to, jak realizowane jest dobro osobowe poszczególnych jej członków ${ }^{17}$. Taka ocena była - jego zdaniem - konieczna do ustalania kierunków wychowania i pracy nad charakterem narodowym. Zrozumiałe, że obyczaj, który sprzeciwia się prawom przyrodzonym i Bożym, uważał za szkodliwy i wymagający odrzucenia. W roli regulatora tych spraw widział bowiem prawodawstwo państwowe i kościelne (w przypadku tradycji katolickiej), a opinię publiczną jako strażnika obyczaju

12 Woroniecki, Katolicka, t. 1, 244.

13 Zob. tamże, 244, 252.

14 Zob. tamże, 248-249.

15 Zob. Mieczysław A. Krąpiec, O ludzka politykę (Lublin: Redakcja Wydawnictw KUL 1998), 144. Bliskie poglądom Krąpca są wypowiedzi Pawła Tarasiewicza i Jacka Grzybowskiego. Zob. np. Paweł Tarasiewicz, Spór o naród (Lublin: Towarzystwo Naukowe KUL 2003), 144.

16 Zob. Jacek Salij, Patriotyzm dzisiaj (Poznań: „W drodze” 2005), 64-65.

17 Podobnie do Woronieckiego pisze na ten temat Jacques Maritain: Człowiek i państwo, przeł. Adam Grobler (Kraków: Wydawnictwo Znak 1993), 67-72. Również: Jan Paweł II: Pamięć i tożsamość. Rozmowy na przełomie tysiącleci (Kraków: Wydawnictwo Znak 2005) 83-92. 
(władzę polityczną jako uprawnioną do formułowania ocen w wymiarze doczesnym, kościelną w ponaddoczesnym).

Ze słów Woronieckiego wynika, że roztropne utrzymanie obyczajów, a więc zachowanie tradycji, o ile nie narusza ona dobra osobowego, ma ogromne znaczenie dla życia moralnego jednostek: stanowi swoistą wykładnię zasad moralnych. Zmuszanie i zachęcanie do porzucania tradycji naraża przeciętnego człowieka na niebezpieczeństwo pozostania bez obyczajów czy dezorientację w dziedzinie wartości: $\mathrm{z}$ obyczajami drugorzędnymi mogą zostać zakwestionowane te, które są ważne dla dobra osoby ${ }^{18}$. Dopełniając wyjaśnienia Woronieckiego, zauważmy za Mieczysławem A. Krąpcem, że pozbawienie kogoś poczucia narodowo-patriotycznego jest równoznaczne z pozbawieniem go „bytowo ważnych relacji”, czyli takich, które leżą u podstaw osobowych działań, chroniąc przed zapadnięciem się w kulturową nicość ${ }^{19}$. Proces gwałtownej zmiany obyczajów oznacza wynarodowianie, a ich zachowanie - postawę patriotyczną. Woroniecki pisze o tym tak: „To wewnętrzne przywiązanie do obyczaju narodowego i gotowość liczenia się z tym wszystkim, co ma on w sobie szlachetnego i pięknego [wyróżnienia moje - M.B.], jest najistotniejszym składnikiem miłości ojczyzny, czyli patriotyzmu $[\ldots] " 20$.

Zauważmy, że obyczaje wszczepiają zbiorowości mocniejsze niż prawa stanowione więzi wewnętrznej jedności, bo wyznaczają społeczności narodowej wspólne kierunki działania, z których wypływa wspólne dobro i dzięki którym wzrasta znaczenie poszczególnych obywateli ${ }^{21}$. Dlatego wszelkie zmiany w dziedzinie obyczajowości powinny być prowadzone z wielką ostrożnością i stopniowo, by nie naruszać „spoistości i harmonii wewnętrznej społeczeństwa”22.

Obyczaje są tym, co różni poszczególne narody między sobą. Woroniecki zaleca roztropność $\mathrm{w}$ prowadzeniu procesów integracyjnych i zaznacza, że proces krystalizowania narodu jest długotrwały (wielowiekowy). Potwierdza to historia Europy: proces kształtowania tożsamości narodowej młodych ludów Zachodu trwał od średniowiecza, a czynnikiem jednoczącym było chrześcijaństwo i system jego norm postępowania, wokół których powstały różne narodowe obyczaje - narodowe kultury ${ }^{23}$. Dziś, gdy jesteśmy świadkami procesów tworzenia nowych więzi międzyludzkich o charakterze ogólnoświatowym czy choćby - ogólnoeuropejskim, gdy postuluje się kształtowanie człowieka o nowej, tzw. otwartej tożsamości, uwagi Woronieckiego zachowują swoją aktualność. Docenienie wychowawczej roli obyczaju narodowego, o którym autor pisze,

18 Zob. Woroniecki, Katolicka, t. 1, 246 oraz Woroniecki, Quaestio, 56-57.

19 Zob. Mieczysław A. Krąpiec, „O patriotyczne wychowanie”, w: Wychowanie do patriotyzmu, red. Waldemar Janiga (Przemyśl - Rzeszów: Wydawnictwo Archidiecezji Przemyskiej 2006), 81.

20 Woroniecki, Katolicka, t. 1, 252-253.

21 Zob. Woroniecki, Quaestio, 21, 43-44.

22 Zob. tenże, Katolicka, t. 1, s. 246.

23 Zob. tenże, Quaestio, 66. 
to drogowskaz dla współczesnych pedagogów jak, w sposób wyważony, oceniać ideologię wielokulturowości i tendencję do relatywizowania tradycji.

Potrzeba takiej refleksji rysuje się wyraźnie w świetle badań, które pokazują, że współczesny człowiek, pozbawiony znaczących autorytetów moralnych, jest bardzo podatny na manipulację, a postęp $\mathrm{w}$ dziedzinie technologii nie przekłada się na postęp społeczno-kulturowy ${ }^{24}$. Kapitalizm globalny pozostawiony sam sobie zmierza raczej do dehumanizacji świata, bo naczelną wartością staje się konsumpcja. Międzynarodowe korporacje dezorganizują dawne struktury społeczne, rozbijają organizację państwową. We współczesnej literaturze socjologicznej istnieje nawet pojęcie retrybizacji, którym opisuje się obserwowane przemiany ${ }^{25}$. Czy lojalność korporacyjna ma zatem zastąpić patriotyzm? Ciekawe w tym względzie mogą być wyniki badań dotyczących patriotyzmu prowadzone w ciągu dwudziestu lat (1990-2010) przez Małgorzatę Brzozowską wśród studentów lubelskich uczelni. Badaczka zwraca uwagę, że w 2010 zmienia się model patriotyzmu - przestaje być nim praca na rzecz ojczyzny ${ }^{26}$. Jednocześnie Brzozowska dostrzega możliwy związek między tą zmianą świadomości patriotycznej a dokonującymi się w tym czasie zmianami programowymi kształcenia w szkołach średnich, a mianowicie ze spisu lektur usunięto pozycje literatury pozytywistycznej.

Poczynione przez badaczkę obserwacje wydają się potwierdzać rosnący stopień trudności w rozpoznawaniu istoty dobra wspólnego w dobie korporacyjnych interesów. Coraz bardziej niejasny staje się sens istnienia wspólnoty narodowej i jej relacja do organizacji państwowej. Konsekwencją tego procesu staje się brak zrozumienia kluczowych elementów tradycji narodowej. Towarzyszyć mu może zbyt emocjonalne przeżywanie patriotyzmu lub eliminowanie z przestrzeni publicznej wartości dawnych obyczajów jako reliktu minionej epoki zagrażającego nowoczesnym postawom obywatelskim ${ }^{27}$.

24 Zob. Leszek Kołakowski, „Samozatrucie otwartego społeczeństwa”, w: tenże, Czy diabet może być zbawiony i 27 innych kazań (Londyn: Aneks 1984), 206-216; Jean-François Lyotard, Postmodernizm dla dzieci. Korespondencja 1982-1985, przeł. Jacek Migasiński (Warszawa: Fundacja Aletheia 1998), 105-106; Herbert Marcuse, Człowiek jednowymiarowy. Badania nad ideologiq rozwiniętego społeczeństwa przemysłowego, przeł. Stanisław Konopacki (Warszawa: Wydawnictwo Naukowe PWN 1991), 300.

25 Zob. Krzysztofek, Szczepański, Zrozumieć rozwój, 293. Autorzy, opisując zjawisko retrybizacji, powołują się m.in. na badania Grażyny Skąpskiej na temat przemian społecznych w Polsce: taż, Lex mercatoria. Ad Meritum 6 (1998). Autorka pisze o narzucaniu pracownikom przez wielkie korporacje własnych praw. Na zewnątrz w swojej polityce korporacje respektują prawa kraju, w którym działają, ale wewnątrz, w stosunku do pracowników, często naruszają prawa człowieka. Szczególnie uwyraźnia się to, gdy załoga jest multikulturowa. Źródłem prawa i norm są wyłącznie poglądy menadżerów i właścicieli: bezwzględna lojalność wobec firmy i identyfikacja z nią są podstawą kultury korporacyjnej.

26 Zob. Małgorzata Brzozowska, Kłopotliwa miłość. Patriotyzm w polskich dyskursach publicystycznych (Lublin: Wydawnictwo Uniwersytetu Marii Curie-Skłodowskiej 2014), 55-58.

27 O elementach składowych patriotyzmu według Woronieckiego zob. M.M. Boużyk, „Patriotyzm w ujęciu Jacka Woronieckiego: podpowiedzi dla współczesnej pedagogiki”. Forum Pedagogiczne 2 (2017): 197-208. 
Szukając podpowiedzi dla działań wychowawczych zorientowanych na dobro wspólne, należy pamiętać, że filozoficznym kontekstem analizy Woronieckiego jest tomizm. W związku z tym oba pojęcia, narodu i państwa, opierają się na charakterystycznej dla tej filozofii koncepcji społeczeństwa. Jest ono definiowane jako rzeczywistość niesamoistna ontycznie i wynikająca z natury człowieka. Człowiek jako osoba jest doskonalszą formą bytowania niż społeczeństwo, ale społeczeństwo warunkuje jego rozwój. Myśliciel - w przeciwieństwie do filozofów oświecenia - a przede wszystkim wbrew indywidualizmowi, nie sprowadza genezy społeczeństwa do umowy społecznej. Wspólnota nie jest postrzegana jako źródło ograniczeń i zniewolenia jednostki ${ }^{28}$, przeciwnie, jest konieczna ontycznie, aby człowiek mógł się realizować w zakresie fizycznym, psychicznym czy duchowym. Przestrzeń powstających społecznych odniesień zawsze suponuje koncepcję dobra łączącego ludzi i stymulującego pracę nad tworzeniem struktur pomagających realizować ten cel - dobro. W języku metafizyki klasycznej można także powiedzieć, że fundament bytu, jakim jest społeczeństwo, tkwi w transcendentalnych (koniecznościowych) relacjach osoby ludzkiej do ostatecznego celu. Aktualizowanie się tych relacji wymaga zaistnienia relacji kategorialnych, ale ich forma jest już względna, $\mathrm{z}$ uwagi na właściwą człowiekowi wolność ${ }^{29}$. W świetle tych wyjaśnień wszelkie formy społeczności, a więc także naród i państwo, są tylko względnie konieczne ${ }^{30}$. Niemniej jednak skoro nie można wychować człowieka poza społecznością, w wymiarze kultury danego czasu należy szukać najlepszych form budowania międzyludzkich relacji, takich, które zapewnią człowiekowi osobową samorealizację. Woroniecki ocenia, że są nimi właśnie naród i państwo. Zapytajmy, co czyniło je tak wyjątkowymi.

\section{Ontologia narodu i państwa}

O patriotyzmie tradycyjnym mówi się często w kontekście znaczenia państw narodowych dla gospodarki industrialnej, a ponadto utożsamia (lub wręcz łączy) z nacjonalizmem jako ideologią państwa narodowego. Wydaje się, jak już wspominaliśmy, że przemiany społeczne, dokonujące się w związku z nową formułą kapitalizmu (tzw. postindustrialnego) i rozwojem nowych technologii, podważają sens istnienia państwa narodowego. Lansowana dziś idea społeczeństwa otwartego jakby kwestionuje sens wychowania patriotycznego.

28 Zob. Woroniecki, Katolicka, t. 1, s. 186-204.

29 Zob. Mieczysław A. Krąpiec, Człowiek i prawo naturalne (Lublin: Redakcja Wydawnictw KUL 1999); tenże, Rozważania o narodzie (Lublin: Fundacja Servire Veritati Instytut Edukacji Narodowej 2004).

30 Zob. Jacek Grzybowski, „Czy relacja - najsłabszy rodzaj bytowości w metafizyce św. Tomasza - może stanowić fundament realnego bytu narodowego". Rocznik Tomistyczny 5 (2016): $247-262$. 
W teoriach rozwoju społecznego zaznacza się, że (po)nowoczesne państwo współpracuje z kapitałem transnarodowym, tak jak kiedyś państwo narodowe z kapitałem narodowym. Skoro ideologia skrajnego nacjonalizmu odwoływała się do koncepcji „człowieka masowego”, dla przeciwwagi uważa się, że człowiek epoki postindustrialnej ma być indywiduum ${ }^{31}$. Sięgając do tekstów Woronieckiego jako źródła podpowiedzi dla poczynań wychowawczych na miarę wyzwań stawianych przez współczesną (postmodernistyczną) kulturę, trzeba pamiętać, że antropologia, którą posługuje się myśliciel w ocenach idei państwa narodowego i nacjonalizmu, nie ma ani znamion indywidualizmu, ani kolektywizmu, ale jest na wskroś personalistyczna. Prześledźmy pokrótce jego tok rozumowania, nie zapominając, że Woroniecki ma na uwadze rozwój moralny człowieka ${ }^{32}$.

Analizę zaczyna od określenia istoty obu form społeczności: narodu i państwa ${ }^{33}$. Zauważa, że z perspektywy ontologicznej ich bytowość tworzą inne formalne zasady, tzn. co innego jednoczy ludzi w naród, a co innego w państwo. Naród jest zbiorowością, której jedność nadają zwyczaje, moralność, język, religia czy pokrewieństwo; państwo jest zbiorowością osób, której jedność wyznaczają prawa i władza państwowa (znaczące jest terytorium, nad którym się ona rozciąga). W związku z przyjętą definicją Woroniecki pokazuje, że obie wspólnoty może łączyć jeden główny cel, przy różnicy stosowanych do jego realizacji środków, czyli celów szczegółowych ${ }^{34}$. Obie wspólnoty mianowicie mają na względzie wspólne dobro zbiorowości, a więc stworzenie każdemu z jej członków możliwości dobrego i cnotliwego życia, tj. zabezpieczeń materialnych i moralnych. Różnica polega natomiast na tym, że państwo zabiega raczej o zewnętrzne zachowanie dobra wspólnego poprzez prawa, a naród ma wpływ na kształtowanie charakterów, w ramach oddziaływań obyczajowych. Te oddziaływania w sposób konieczny warunkują realizowanie dobra wspólnego.

Zajmując się problemem roli czynników narodowych i państwowych w rozwoju moralnym człowieka, autor zauważa, że naród i państwo nie są wolne od praw moralnych, które kierują działaniami poszczególnych jednostek. Prawo moralne porządkuje wszystkie dziedziny ludzkiego życia, zarówno indywidualnie, jak i społecznie, tworzy dla nich stałe normy działania i w tym sensie dotyczy zarówno jednostki, jak i społeczności. Należy jednak pamiętać, że prawo moralne nie jest proste i musi być interpretowane stosownie do jedności bytowej, z którą

31 Zob. Karl R. Popper, Społeczeństwo otwarte i jego wrogowie, przeł. Halina Krahelska, t. 1-2 (Warszawa: Wydawnictwo Naukowe PWN 1993).

32 Zob. także analizy: Jacka Grzybowskiego, „Czy idee nacjonalistyczne zakwestionują społeczeństwo liberalno-demokratyczne? Rozważania o przyszłości narodu w świecie diaspory i bezdomności", Civitas: Studia z filozofii polityki 14 (2012), 137-163; Katarzyny Kalinowskiej, Jacek Woroniecki o społeczeństwie i państwie (Lublin: Fundacja Servire Veritati Instytut Edukacji Narodowej 2005); Ulricha Schradego, „Problematyka narodu i ojczyzny w ujęciu J. Woronieckiego i I.M. Bocheńskiego", Arcana 3 (2000): 60-78.

33 Zob. Woroniecki, Quaestio, 15-17.

34 Zob. tamże, 22-23. 
mamy do czynienia: sposób istnienia człowieka ma charakter substancjalny, społeczności - tylko relacyjny ${ }^{35}$. W związku z tym prawa moralne wymagają dostosowania w zależności od tego, czy dotyczą działań jednostki, czy społeczności, takich jak naród i państwo. Jednostki nie powinny np. dokonywać samosądu, ale korzystać z władzy sądowniczej lub pozostawić rozwiązanie sprawy Bogu. Tylko w tym znaczeniu można powiedzieć, że prawa te się różnią, że czegoś można zabraniać państwu lub narodowi, a czegoś jednostce ${ }^{36}$. Brak praw moralnych w działaniu społeczności grozi anarchią moralną, zarówno w życiu wewnętrznym państwa, jak i międzynarodowym. Skutkiem tego jest dezintegracja wspólnoty narodowej czy wykorzystywanie jednych państw przez drugie ${ }^{37}$. „Życie narodowe - zauważa Woroniecki - winno być podporządkowane prawom moralności, ponieważ w gruncie rzeczy nie jest niczym innym jak jednym z czynników całokształtu naszego życia moralnego"38. Autor ma tu na myśli zarówno prawa przyrodzone, jak i nadprzyrodzone. Harmonijne łączenie tych dwóch dziedzin jest charakterystyczne dla całej myśli wychowawczej Woronieckiego i ze względu na trwające procesy laicyzacji życia można traktować ją jako ważną podpowiedź dla współczesnych pedagogów.

W świetle słów Woronieckiego wyraźnie rysuje się także relacja między państwem a obywatelem czy organizacjami ponadpaństwowymi a narodami, z którymi mamy do czynienia na dzisiejszym etapie przemian społecznych. Pedagog zaznacza, że państwo (dodajmy: i struktury ponadpaństwowe) może siłą oddziaływać na obywateli tylko w granicach prawa naturalnego i pozytywnego. Jeśli je przekracza, nie może wymagać od obywateli posłuszeństwa. Zatem państwo, działając przeciwko narodowi, osłabia swój autorytet. $\mathrm{W}$ antropologii personalistycznej, do której myśliciel się odwołuje, akcent pada na podmiotowość obywateli w sprawowaniu władzy. Państwo nie ma prawa gwałcić sumienia obywateli i ich wolności, ale jednocześnie każdy obywatel ponosi odpowiedzialność za ten wymiar dobra wspólnego, jakim jest państwo. To właśnie m.in. w korzystaniu $\mathrm{z}$ tego prawa i respektowaniu tego obowiązku ma wyrażać się patriotyzm. Dlatego w procesie wychowania istotną rolę odgrywa wychowanie narodowe.

Woroniecki kładzie nacisk na współdziałanie państwa i narodu, tzn. łączenie właściwych im narzędzi kształtowania wspólnoty: praw i obyczajów ${ }^{39}$. O ile prawa oddziałują na człowieka z zewnątrz, obyczaj - od wewnątrz, przez uformowane sumienie i charakter. Woroniecki zaznacza, że same prawa nie są w stanie zabezpieczyć dobra wspólnego (są ontycznie za słabe), dlatego potrzebują wsparcia ze strony obyczajów. Inaczej można powiedzieć, że same regulacje prawne nie wystarczają do kształtowania postaw obywatelskich. Wzmocnienie

\footnotetext{
35 Zob. tamże, 33-40.

36 Zob. tamże, 34.

37 Zob. tamże, 33.

38 Tamże, 61.

39 Zob. tamże, 22-23.
} 
dobra wspólnego dokonuje się szczególnie wtedy, gdy prawa zyskują podstawę w obyczajach. Pomijając oczywisty fakt, że dzięki prawom członkowie społeczności powinni być chronieni przed czynami ludzi zdeprawowanych, a także uzyskać wsparcie w osiągnięciu godnego poziomu życia, należy przede wszystkim dostrzec, że poprzez prawa państwo ustanawia jedność działania społeczności, podnosi też znaczenie jednostek. Woroniecki wyjaśnia: „Ta ogólna misja państwa tak głęboko powiązana jest $\mathrm{z}$ istotnym elementami natury ludzkiej, że nigdy nie powinno jej zabraknąć ludziom - nawet w stanie pierwotnej sprawiedliwości” ${ }^{40}$.

Naród, podobnie jak państwo, ma być jego zdaniem wsparciem dla członków społeczności. Państwo, w którym panuje zgodność co do obyczajów, służy moralnemu rozwojowi człowieka:

Chociaż bowiem państwo i naród mają wspólny cel i w dążeniu do niego każde $\mathrm{z}$ nich wnosi coś innego, [to] z pewnością o tyle szybciej ten cel osiąga, o ile bardziej będą zgodne we wzajemnym działaniu. Najdogodniejsza po temu sytuacja może zaistnieć w państwie narodowym, gdzie prawa państwowe $\mathrm{w}$ sposób doskonały zgadzają się $\mathrm{z}$ obyczajami i gdzie nie ma żadnej rozbieżności między dobrem wspólnym państwa a dobrem wspólnym narodu. Rozbieżność taka może łatwo się pojawić wszędzie tam, gdzie w jednym państwie żyje wiele narodów: te same prawa bowiem nie mogą harmonizować $\mathrm{w}$ równym stopniu $\mathrm{z}$ obyczajami wszystkich [tych] narodów. Najbardziej ujawnia się to $\mathrm{w}$ wychowaniu i kształceniu, które zawsze $\mathrm{w}$ mniejszym lub większym stopniu są regulowane przez prawa państwowe, a przecież powinny opierać się na obyczajach poszczególnych narodów. Jeśli prawa będą zbyt ujednolicone, obyczaje różnych narodów będą z konieczności to odczuwać; jeśli natomiast jednolitość praw ustąpi różnorodności obyczajów, załamie się wewnętrzna jednolitość państwa, która stanowi o jego sile [wyróżnienia moje-M.B. $]^{41}$.

Ten fragment wydaje się trafnym komentarzem w kontekście obserwowanych napięć współczesnego świata, w szczególności Europy. Woroniecki, jak łatwo zauważyć, daleki jest od tworzenia apoteozy państwa narodowego i stara się wyważyć racje, które przemawiają za organizacją takiego państwa. W centrum uwagi pedagoga stoi człowiek oraz jego moralny rozwój. Teoria państwa jednonarodowego - jak zauważa myśliciel - nie zawsze daje się stosować; ponadto życie w takim państwie nie jest warunkiem bezwzględnym dla osiągnięcia przez człowieka ostatecznego celu życia, a więc i do uporządkowania sfery moralnej ${ }^{42}$.

Jeśli chodzi o procesy integracyjne w skali Europy, ciekawe mogą okazać się także rozważania Woronieckiego dotyczące ustalenia nadrzędności państwa

\footnotetext{
40 Tamże, 20.

41 Tamże, 54.

42 Zob. tamże.
} 
względem narodu oraz narodu względem państwa ${ }^{43}$. W zależności od rozpatrywanego aspektu wzajemnych relacji priorytet raz może być po stronie państwa, raz narodu. Państwo, którego celem jest troska o zewnętrzną jedność społeczności i które z tego powodu wyposażone zostało w środki oddziaływania w celu zachowania tej jedności, wyraźniej manifestuje swoją działalność niż naród; jest skuteczniejsze w stosowaniu środków (prawa) gwarantujących jedność. Naród natomiast swoją wyższość w stosunku do państwa manifestuje przez to, że wywiera większy wpływ na człowieka: obyczaje decydujące o tożsamości narodowej nadają działaniu człowieka jedność i stałość. Tak więc naród przewyższa państwo w kwestii bardziej istotnej:

[...] jeśli bowiem uważnie zastanowimy się nad dobrem wspólnym społeczności ludzkiej, zobaczymy, że to, do czego przyczynia się życie narodowe, posiada większe znaczenie niż to, co osiąga się na płaszczýnie państwa. Życie w narodzie daje bowiem społeczności ludzkiej jedność wewnętrzną, opartą na wychowaniu w obyczajach i taka jedność w sposób oczywisty przewyższa jedność zewnętrzną, którą państwo uzyskuje poprzez prawa państwowe i środki represyjne ${ }^{44}$.

Podsumowując: naród przewyższa państwo, ponieważ ma większy wpływ na rozwój sprawności moralnych człowieka: obyczaje bardziej niż prawa przyczyniają się do zdobycia i utrwalenia cnót. Tym też można wytłumaczyć fakt, że jedność państwa jest mniej stabilna i łatwiej podlega zmianom. Jakkolwiek więzi obywatelskie, jak zauważa pedagog, „nie mniej niż poczucie więzi narodowych, wywodzą swój początek z substancjalnych elementów natury ludzkiej, i chociaż również są konieczne, to jednak są mniej trwałe i nie tak głęboko przenikają życie moralne człowieka"45.

Omawiane zależności między państwem a narodem Woroniecki wyjaśnia, odwołując się do realistycznej metafizyki, a w szczególności do arystotelesowskiej teorii przyczyn, zauważając, że:

[...] w państwie, które się składa z jednego narodu, władza państwowa kieruje życiem narodu jako przyczyna sprawcza, gdyż jest wyposażona w bardziej skuteczne środki. Natomiast w sensie przyczyny celowej [to] raczej naród kieruje państwem, ponieważ celem działalności państwa jest moralne życie obywateli, którego najlepiej strzegą obyczaje narodowe. Przyczyna celowa jest zaś pierwszą wśród przyczyn, dlatego też i naród w sposób istotny przewyższa państwo ${ }^{46}$.

43 Zob. tamże, 41-46.

44 Tamże, 43.

45 Tamże, 49.

${ }_{46}$ Tamże, s. 45. Wyjaśnijmy, że chodzi o charakterystyczne dla wyjaśniania metafizycznego szukanie ostatecznych przyczyn badanych faktów, tj. przyczyny sprawczej, wzorczej, materialnej i celowej. Arystoteles określił przyczynę celową jako poznawczo i bytowo kluczową. Zob. więcej: Mieczysław A. Krąpiec, Metafizyka. Zarys podstawowych zagadnień (Lublin: Towarzystwo Naukowe KUL 1978), 433-467. 
Woroniecki podkreśla, że w imię sprawiedliwości nie należy odmawiać narodowi obrony swych obyczajów, ale pozwolić, by utworzył własne państwo. Myśliciel przyznaje, że idea państwa narodowego, w radykalnej postaci, może być źródłem różnych napięć, dawkowana jednak $\mathrm{z}$ umiarem (a więc z uwzględnieniem okoliczności i warunków życia społecznego), odzwierciedla pewną naturalną tendencję rodzaju ludzkiego i może przynieść niemałą korzyść dla moralnego rozwoju społeczeństwa obywatelskiego. Utopią - jak zauważa myśliciel - jest stan idealnego pokoju, a za bezzasadne uważa założenie, że powodem napięć jest państwo narodowe, zatem jego zlikwidowanie będzie gwarantem międzynarodowego bezpieczeństwa.

Ta myśl Woronieckiego może wydawać się bliska idei Europy ojczyzn Charlesa de Gaulle’a i liczyć na zrozumienie niektórych badaczy współczesnych. Państwa narodowe - uważają naukowcy - są potencjalnie czynnikiem sprzyjającym humanizacji procesów globalizacyjnych, tym bardziej że (w obrębie kultury Zachodu) mają duże zasługi w sferze demokracji, państwa obywatelskiego, rozwiązań kwestii socjalnych czy zapewnienia minimum sprawiedliwości i godnego życia ${ }^{47}$. Tylko od państwa i jego rządu obywatele mogą domagać się sprawiedliwości i zmian. Ekonomia nie może więc podporządkowywać sobie polityki ${ }^{48}$. Omawiając założenia programowe rekonstrukcji zjednoczonej Europy, Krzysztof Szczerski, politolog, podkreśla potrzebę budowania rzeczywistej wspólnoty wolnych narodów i równych państw ${ }^{49}$. Jakkolwiek dziś problemy ekonomiczno-polityczne wymagają perspektywy szerszej niż narodowa, to wola ich pokojowego rozwiązywania jest jedynym fundamentem budowania relacji między narodami.

Dokonujące się przemiany społeczno-kulturowe, a w szczególności laicyzacja życia, każą zapytać jeszcze o czynnik religijny w kształtowaniu nowoczesnego patriotyzmu. Dziś „katolickość” bywa oceniana negatywnie: argumentuje się, że katolicyzm, charakterystyczny dla polskiego społeczeństwa, nie da się pogodzić z demokracją i jest źródłem tradycyjnego (czytaj: anachronicznego) patriotyzmu wielu Polaków. Tymczasem Woroniecki w swojej refleksji nad wychowaniem widzi zawsze kwestie moralne w kontekście wartości chrześcijańskich ${ }^{50}$. Sprawiedliwość współdzielczą, w ramach której rozpatrywał cnotę patriotyzmu,

47 Zob.: Grzybowski, „Czy idee nacjonalistyczne”; Henryk Hermann, „Jakiego patriotyzmu potrzebują dziś: Polska i Polacy?”, w: Patriotyzm wspótczesnych Polaków, red. Aleksandra Skrabacz (Warszawa: Dom Wydawniczy Elipsa 2012), 73-87; Krzysztofek, Szczepański, Zrozumieć rozwój, 298-299.

48 Zob. Hans-Peter Martin, Harald Schumann, Pułapka globalizacji. Atak na demokracje i dobrobyt, przeł. Marek Zybura (Wrocław: Wydawnictwo Dolnośląskie 1999), 253.

49 Zob. Krzysztof Szczerski, Utopia europejska. Kryzys integracji i polska inicjatywa naprawy (Kraków: Biały Kruk 2017), 231-232, 247.

50 Zob. Gabriela Wistuba, Prowadzić ku Zbawcy. Duszpasterstwo w nauczaniu i posłudze o. Jacka Woronieckiego OP (Sandomierz: Wydawnictwo Diecezjalne i Drukarnia w Sandomierzu 2011), 247-285; Kalinowska, Jacek, 110-131. 
łączy z chrześcijańską prawdą o miłości Boga i bliźniego ${ }^{51}$. Pracę nad charakterem traktuje jako walkę o to, by pycha nie zawładnęła sercem człowieka. Postęp $\mathrm{w}$ tej pracy oznaczał dlań postęp w miłości Boga, zaś regres wiązał z utrwalaniem egoizmu, a w krańcowych przypadkach nawet z przejawami pogardy wobec $\operatorname{Boga}^{52}$. Postawy obywatelskie były dla niego konsekwencją rozwoju moralnego, a ten ważnym probierzem duchowej dojrzałości ${ }^{53}$. Uważał, że chrześcijańska pokora, umiejąca odnaleźć w przeciwniku dobre strony, może przynosić korzyść w kształtowaniu stosunków międzynarodowych, bo „chroni od rozpamiętywania, tak niebezpiecznego dla jasności sądu, oraz przed manią wielkości, która przywiodła do zguby niejeden naród"54. Jeśli chodzi o kwestię obyczajów narodowych, zastanawiał się nad ich rolą w planach Bożej opatrzności. W ich wielości upatrywał przejaw bogactwa kulturowego ludzkości: każdy naród jest potrzebny, a jego niepowtarzalność to dar od Boga (tamże, s. 122).

Analizę złożonego zjawiska relacji między katolicyzmem Polaków a ich postawami patriotycznymi podejmuje także przywoływany już przez nas teolog Jacek Salij. Badacz pokazuje m.in., że myśl o tym, że postawy obywatelskie i zaangażowanie społeczne mogą mieć źródło $\mathrm{w}$ wierze, jest trudna do zaakceptowania nawet przez naukowców ${ }^{55}$. Jednocześnie autor daje wiele przykładów na pozytywny wpływ chrześcijaństwa na kształtowanie postaw patriotycznych Polaków. Twierdzi, że w okresie nasilonych ruchów skrajnie nacjonalistycznych Polacy byli w stanie oprzeć się tej ideologii dzięki temu, że wcześniej, tj. w okresach zaborów, „nie pozwoli się złamać swoim cierpieniom, ale potrafili je wykorzystać dla własnego oczyszczenia" ${ }^{56}$. Podobne wnioski o wadze formacji chrześcijańskiej dla postaw obywatelskich i dojrzałego patriotyzmu przedstawia na podstawie własnych badań Andrzej Sułek w pracy: Psychospołeczne uwarunkowania patriotyzmu i nacjonalizmu $(2012)^{57}$.

Podsumowując nasze rozważania, warto zauważyć, że w namyśle nad współczesną formą patriotyzmu ważne jest, by oprzeć go na koncepcji narodu odwołującej się do personalistycznej koncepcji człowieka jako bytu jednostkowego i społecznego zarazem. Chodzi o to, by nie traktować wybiórczo czynników konstytuujących naród, takich jak: język, wspólnota terytorialna, więzy krwi, ale dostrzec wagę uporządkowania sfery obyczajowej w integracji społecznej. Dla koncepcji personalistycznej zasadnicza jest zgodność zachodząca między celem

51 Zob. Woroniecki, Katolicka, t. 2-2, s. 95.

52 Zob. tamże, t. 1, 401.

53 Zob. tenże, „Moralność a religia”, w: tenże, U podstaw kultury katolickiej (Lublin: Fundacja Servire Veritati Instytut Edukacji Narodowej 2002), 55-70.

54 Zob. Woroniecki, Katolicka, t. 2-2, 128.

55 Zob. Salij, Patriotyzm, 13-16.

56 Tamże, s. 76-77.

57 Zob. Andrzej Sułek, Psychospołeczne uwarunkowania patriotyzmu i nacjonalizmu (Kraków: Wydawnictwo Naukowe Uniwersytetu Papieskiego Jana Pawła II 2012). 
narodu a obiektywnym celem osobowym, którą uwyraźnia namysł filozoficzny. Należy podkreślić, że chodzi o dobro człowieka jako osoby, a nie o doświadczanie przyjemności czy powiększanie czyjejś sfery posiadania. Celem narodu jest zabezpieczenie osobowego dobra jego członków. Taki punkt odniesienia w życiu społecznym implikuje stworzenie przestrzeni dla okazywania wzajemnego szacunku jednego narodu wobec drugiego i uznania ich odrębności kulturowej za pozytywną wartość. Ponadto zyskuje się obiektywną podstawę do oceny działań narodowych, państwowych i ponadpaństwowych.

Woroniecki, postulując kryterium moralne oceny stosunków społecznych, aktywnie współtworzył personalistyczną teorię narodu. Filozofia realistyczna, do której teoria ta się odwołuje, nie przeciwstawia patriotyzmowi tendencji integracyjnych między narodami, ale przyznaje narodom prawo do samostanowienia, czego najpełniejszym wyrazem jest posiadanie przez naród własnego państwa. Tożsamość narodowa jest ważnym czynnikiem formacji kulturowej osoby i właśnie ona jest źródłem patriotycznych postaw. W związku z tym w procesie wychowania istotną rolę powinno odgrywać wychowanie narodowe, o które upominał się Woroniecki. Taką koncepcję, w oparciu o teksty pedagoga, wyczerpująco opracowała Katarzyna Kalinowska (2005). Badaczka wskazała na następujące jej elementy: (1) wychowanie w poczuciu potrzeby wolności i niepodległości Polski; (2) zrozumienie istoty wolności i współdziałania narodów jako gwarancji wolności własnego narodu; (3) przyjęcie zasad moralnych jako jedynej podstawy samorządności, wolności i ładu społecznego; (4) wychowanie w celu wypracowania wolności i samorządności jednostek; (5) wykształcenie nawyku współdziałania całego społeczeństwa w granicach ładu społecznego, w służbie narodu, żyjącego i rozwijającego się przez działanie każdego obywatela, a nie tylko wybranych jednostek; (6) poszanowanie godności człowieka; (7) wypracowanie zdolności do samorzutnej i ofiarnej pracy na rzecz społeczeństwa i państwa; (8) poszanowanie osoby ludzkiej i jej prawa do wolności ${ }^{58}$.

Dla aktualnych poszukiwań najlepszej formuły patriotyzmu ważne jest wyjaśnienie, że jej źródło tkwi w koncepcji społeczeństwa, w tym w koncepcji narodu i państwa. Lansowany w ostatnich dekadach jako nowoczesny patriotyzm konstytucyjny, który proponował m.in. Habermas, pisząc o możliwości wyodrębnienia się $\mathrm{z}$ różnych kultur narodowych jednej kultury politycznej, opiera się na koncepcji narodu jako umowy społecznej warunkowanej prawem, natomiast model Woronieckiego odwołuje się do koncepcji narodu jako bytu realnego o charakterze relacyjno-kulturowym: naród nie istnieje przez siebie, ale dzięki jednostkom budującym wspólnotę ze względu na przyjmowane wartości. Oba patriotyzmy mają inne uwarunkowania ontologiczne: konstytucyjny czerpie je z idealistycznej metafizyki, a model Woronieckiego z metafizyki realistycznej. W wysiłku wypracowania modelu patriotyzmu adekwatnego do trwających w Europie procesów

\footnotetext{
58 Zob. Kalinowska, Jacek, 131.
} 
integracyjnych należy uwzględnić komplementarność oddziaływania wychowawczego narodu i państwa na jednostkę, natomiast spoiwem toczących się wokół takiego modelu dyskusji powinna być przede wszystkim troska o moralny rozwój osoby.

Streszczenie: Celem artykułu jest odczytanie koncepcji narodu i państwa Jacka Woronieckiego we współczesnych kontekstach globalizacji i integracji kulturowej, by w ten sposób uzyskać klucz do ponownego definiowania patriotyzmu. Artykuł został podzielony na trzy części. W pierwszej stawia się pytanie o znaczenie społeczności narodowej i państwowej w ludzkim życiu. W drugiej omawia się kwestię tradycji narodowej, czynnika postrzeganego we współczesnych dyskursach na temat patriotyzmu jako kontrowersyjny. W trzeciej przedstawia się ontologię narodu i państwa sformułowaną przez Woronieckiego. Podjęcie tych ważnych tematów daje sposobność do upowszechniania myśli polskiego pedagoga.

W oparciu o przeprowadzone analizy uzasadnia się, że koncepcja współczesnego patriotyzmu powinna nie tylko uwzględniać czynnik kulturowy, ale i nie przeciwstawiać go legislacyjnemu. Dowodzi się, że oba typy społeczności, naród i państwo kształtują tożsamość osobową człowieka i jego działania społeczne. Mianowicie naród i państwo posługują się innymi, ale komplementarnymi środkami w wychowywaniu jednostki: podczas gdy naród przez obyczaje wpływa na kształtowanie charakteru członków społeczności, państwo troszczy się o prawa. Dzięki wyjaśnieniu ontycznych uwarunkowań obu formacji społecznych odsłania się fundamentalna zasada ich istnienia, tzn. moralne wychowanie jednostki. Ta zasada ma uniwersalne znaczenie i może być cenna w redefiniowaniu patriotyzmu adekwatnie do potrzeb współczesnej kultury.

Słowa kluczowe: naród, państwo, patriotyzm, globalizm, procesy integracyjne, rozwój moralny, tradycja

\section{Bibliografia}

Bauman, Zygmunt. Globalizacja i co z tego dla ludzi wynika, przeł. Ewa Klekot. Warszawa: Państwowy Instytut Wydawniczy, 2000.

Boużyk, Maria M. „Patriotyzm w ujęciu Jacka Woronieckiego: podpowiedzi dla współczesnej pedagogiki”. Forum Pedagogiczne 2 (2017): 197-208.

Brzozowska, Małgorzata. Kłopotliwa miłość. Patriotyzm w polskich dyskursach publicystycznych. Lublin: Wydawnictwo Uniwersytetu Marii Curie-Skłodowskiej, 2014.

Fukuyama, Francis. Koniec historii, przeł. Tomasz Bieroń, Marek Wichrowski. Poznań: Wydawnictwo Zysk i S-ka, 1997.

Grzybowski, Jacek. „Czy relacja - najsłabszy rodzaj bytowości w metafizyce św. Tomasza - może stanowić fundament realnego bytu narodowego”. Rocznik Tomistyczny 5 (2016): 247-262.

Grzybowski, Jacek. Byt, tożsamość, naród. Próba wyjaśnienia formuly „tożsamość narodowa” w perspektywie metafizyki. Kęty: Wydawnictwo Marek Derewiecki, 2012.

Grzybowski, Jacek. „Czy idee nacjonalistyczne zakwestionują społeczeństwo liberalno-demokratyczne? Rozważania o przyszłości narodu w świecie diaspory i bezdomności”. Civitas: Studia z filozofii polityki 14 (2012): 137-163. 
Habermas, Jürgen. Obywatelstwo a tożsamość narodowa. Rozważania nad przyszłościa Europy, przeł. B. Markiewicz. Warszawa: Instytut Filozofii i Socjologii PAN, 1993.

Hermann, Henryk. „Jakiego patriotyzmu potrzebują dziś: Polska i Polacy?”. W: Patriotyzm wspótczesnych Polaków, red. Aleskandra. Skrabacz, 73-87.Warszawa: Dom Wydawniczy Elipsa, 2012.

Jan Paweł II. Pamięć i tożsamość. Rozmowy na przełomie tysiącleci. Kraków: Wydawnictwo Znak, 2005.

Kalinowska, Katarzyna. Jacek Woroniecki o społeczeństwie i państwie. Lublin: Fundacja Servire Veritati Instytut Edukacji Narodowej, 2005.

Kołakowski, Leszek. „Samozatrucie otwartego społeczeństwa”. W: tenże, Czy diabeł może być zbawiony i 27 innych kazań, 206-216. Londyn: Aneks, 1984.

Krąpiec, Mieczysław A. Człowiek i prawo naturalne. Lublin: Redakcja Wydawnictw KUL, 1999.

Krąpiec, Mieczysław A. Metafizyka. Zarys podstawowych zagadnień. Lublin: Towarzystwo Naukowe KUL, 1978.

Krąpiec, Mieczysław A. O ludzką politykę. Lublin: Redakcja Wydawnictw KUL, 1998.

Krąpiec, Mieczysław A. „O patriotyczne wychowanie”. W: Wychowanie do patriotyzmu, red. Waldemar Janiga. 77-81. Przemyśl - Rzeszów: Wydawnictwo Archidiecezji Przemyskiej, 2006.

Krąpiec, Mieczysław A. Rozważania o narodzie. Lublin: Fundacja Servire Veritati Instytut Edukacji Narodowej, 2004.

Król, Marcin. Patriotyzm przyszłości. Warszawa: Wydawnictwo „Szklane Domy”, 2004.

Krzysztofek, Kazimierz, Szczepański, Marek S. Zrozumieć rozwój. Od społeczeństw tradycyjnych do informacyjnych. Katowice: Wydawnictwo Uniwersytetu Śląskiego, 2005.

Lyotard, Jean-François. Postmodernizm dla dzieci. Korespondencja 1982-1985, przeł. J. Migasiński. Warszawa: Fundacja Aletheia, 1998.

Marcuse, Herbert. Człowiek jednowymiarowy. Badania nad ideologia rozwiniętego społeczeństwa przemysłowego, przeł. Stanisław Konopacki. Warszawa: Wydawnictwo Naukowe PWN, 1991.

Maritain, Jacques. Człowiek i państwo, przeł. Adam Grobler. Kraków: Wydawnictwo Znak, 1993.

Martin, Hans-Peter, Schumann Harald. Pułapka globalizacji. Atak na demokrację i dobrobyt, przeł. Marek Zybura, Wrocław: Wyd. Dolnośląskie, 1999.

Popper, Karl R. Społeczeństwo otwarte i jego wrogowie, przeł. Halina Krahelska, t. 1-2, Warszawa: Wydawnictwo Naukowe PWN, 1993.

Salij, Jacek. Patriotyzm dzisiaj. Poznań: „W drodze”, 2005.

Schrade, Ulrich. „Problematyka narodu i ojczyzny w ujęciu J. Woronieckiego i I.M. Bocheńskiego”. Arcana 3 (2000): 60-78.

Sułek, Andrzej. Psychospołeczne uwarunkowania patriotyzmu i nacjonalizmu. Kraków: Wydawnictwo Naukowe Uniwersytetu Papieskiego Jana Pawła II, 2012.

Szczerski, Krzysztof, Utopia europejska. Kryzys integracji i polska inicjatywa naprawy. Kraków: Biały Kruk, 2017.

Tarasiewicz, Paweł. Spór o naród. Lublin: Towarzystwo Naukowe KUL, 2003.

Toffler, Alvin. Trzecia fala, przeł. Ewa Woydyłł, Michał Kłobukowski. Warszawa: Państwowy Instytut Wydawniczy, 1997.

Wistuba, Gabriela. Prowadzić ku Zbawcy. Duszpasterstwo w nauczaniu i posłudze o. Jacka Woronieckiego OP, Sandomierz: Wydawnictwo Diecezjalne i Drukarnia w Sandomierzu, 2011.

Woroniecki, Jacek. Katolicka etyka wychowawcza, Lublin: Redakcja Wydawnictw KUL, 1986.

Woroniecki, Jacek. „Moralność a religia”. W: tenże, U podstaw kultury katolickiej, 55-70. Lublin: Fundacja Servire Veritati Instytut Edukacji Narodowej, 2002.

Woroniecki, Jacek. Quaestio disputata de natione et statu civili - O narodzie i państwie, przeł. R. Maliszewski. Lublin: Fundacja Servire Veritati Instytut Edukacji Narodowej, 2004. 